\title{
A arte é minha cura! A importância da arte para os usuários dos Centros de Atenção Psicossocial - CAPS
}

\author{
Everton Roberto de Oliveira \\ Universidade de São Paulo \\ evertonr.oliveira@outlook.com \\ https://orcid.org/0000-0002-7042-4955
}

A relação entre arte e saúde mental foi tema de "re.construindo mundos: arte, direitos humanos e cidadania nos Centros de Atenção Psicossocial CAPS" dissertação que apresentei ao Diversitas, Programa de Pós-Graduação Interdisciplinar em Humanidades, Direitos e Outras Legitimidades da Universidade de São Paulo, sob orientação da professora Sandra Regina Chaves Nunes, com apoio essencial da CAPES. Nessa pesquisa constituída por uma história oral viva e do tempo presente que, interessada pela educação e por novos horizontes de futuro, ouviu usuários, familiares e trabalhadores desse importante serviço público de atenção e cuidados à saúde mental no país.

Assunto urgente e necessário, visto que, a Organização Mundial da Saúde - OMS afirma que uma em cada quatro pessoas no mundo sofrerá de sua condição de saúde mental ao longo da vida. Já o Ministério da Saúde (2008, p. 10) estima que no Brasil cerca de $6 \%$ da população abuse ou é dependente de substâncias psicoativas e que outros $3 \%$ possua transtornos mentais graves ou severos; dados que revelam uma substancial quantidade de pessoas que carece ou vai carecer de cuidados nessa área e deverão receber os serviços prestados pelos CAPS. Serviços que integram uma ampla Rede de Atenção Psicossocial - RAPS, que ainda está sendo estruturada pelo Sistema Único de Saúde - SUS.

Com a missão de prestar atendimento humanizado e de portas abertas, os Centros de Atenção Paicossocial são pontos de atenção psicossocial especializada e hoje há mais de dois mil e seiscentos ${ }^{1}$ deles espalhados pelo país. Considerados estratégicos para a Reforma Psiquiátrica brasileira, por substituírem os terríveis manicômios, devem evitar as internações, envolver toda comunidade e garantir o exercício pleno de cidadania aos seus usuários, pautados pelo respeito aos direitos humanos, pela autonomia e pela liberdade dessas pessoas e, no território em que atuam, têm de ultrapassar seus próprios portões.

Em diferentes modalidades (para pessoas com transtornos mentais graves e persistentes - CAPS, para aqueles com necessidades decorrentes do uso

1 Disponível em <https://www.gov.br/pt-br/noticias/saude-e-vigilancia-sanitaria/2020/01/investimento-emsaudementalcresceuquase 200\#: : text =Centros\%20de\%20Apoio\%20Psicossocia1\%20(Caps)\&tex$\mathrm{t}=\mathrm{O} \% 2$ SUS $\% 20$ conta $\% 20$ com $\% 202.661$, Psicossocial $\% 20 \mathrm{em} \% 20$ todo $\% 20 \mathrm{o} \% 20 \mathrm{pa} \% \mathrm{C} 3 \%$ ADs. $>$ Acesso em: 25 jan. 2021 
de álcool e outras drogas - CAPS AD ou para crianças e adolescentes - CAPS IJ) eles são constituídos por distintas equipes multiprofissionais, que atuam sob uma ótica interdisciplinar, tanto em situações de crise, quanto nos processos de reinserção e reabilitação psicossocial de seus usuários e familiares.

Nesses Centros de Atenção Psicossocial - CAPS, os cuidados oferecidos são orientados por meio da construção de um Projeto Terapêutico Singular - PTS, instrumento que envolve a equipe, o usuário e sua família. O Projeto Terapêutico Singular acompanha o paciente em "sua história, cultura, projetos e vida cotidiana", cuja estratégia de composição contém, além de outras atividades terapêuticas, as chamadas práticas expressivas, comunicativas e corporais. Tais atividades são voltadas às artes plásticas, às artes cênicas, à leitura e à literatura ou à música, por exemplo, configurando-se como a principal ferramenta nos processos de reabilitação psicossocial dos usuários, reza a legislação.

Afinal, reconhecidos pensadores defendem o acesso à arte como uma condição para a existência humana e direito de todo cidadão, além de Nise da Silveira (1992, p.17) que comprova sua potência como força "autocurativa", sua necessidade e importância como terapia alternativa a um tratamento medicamentoso e de reclusão para aqueles que atravessam a experiência da loucura. Essa potência curativa pode ser constatada no testemunho de um jovem frequentador de um desses CAPS em Sorocaba, interior de São Paulo, enquanto conversávamos, ele afirmou: "a arte é minha cura!"

Entretanto, vivemos um processo de desinstitucionalização psiquiátrica desde meados dos anos 80 e que continua em andamento por aqui. A Secretaria Estadual de Saúde de São Paulo (2015, p. 14) ressalta que "nos últimos anos houve pouco avanço nessa questão", pois, os investimentos em serviços de atenção comunitária, como os CAPS, por exemplo, tiveram pouca adesão, visto que grande parte dos recursos financeiros foi, durante muito tempo, destinada à área hospitalar, destacando a forte resistência da sociedade em incluir essas pessoas em suas comunidades, fora do asilo. Isso expressaria claramente, nas palavras de Pedro Delgado (2011, p. 119) que "o embate ideológico e de modelos de atenção persiste e a agenda política de defesa dos princípios da lei permanece atual", sobretudo, no presente momento político de conflitos e retrocessos na área.

É preciso lembrar que a região de Sorocaba foi considerada, por um longo período, um dos maiores pólos manicomiais do país e ficou conhecida nacionalmente pelos inúmeros episódios de violação dos direitos humanos, de maus-tratos aos internos dessas instituições. Além de greves e paralisações dos servidores, de tal maneira que, ainda hoje, o município é palco de discussões e controvérsias a respeito dos serviços prestados por estes Centros.

Além disso, vivemos em meio a um processo de consolidação de profundas mudanças no sistema psiquiátrico do país e estudos como o do Conselho Regional de Medicina de São Paulo (2010, p. 17) apontam que há falta de avaliações sobre o serviço e também que não há transparência na divulgação dos escassos dados existentes sobre a atuação desse sistema psiquiátrico. As constatações do Conselho Regional de Medicina expõem 
à sociedade brasileira um dilema sobre o qual poucos estudiosos têm se debruçado para responder: qual é a importância da arte para os usuários de um Centro de Atenção Psicossocial, novo modelo de atenção e cuidados à saúde mental que ainda se assenta no país?

Em busca de respostas a essa questão relevante para quem de fato vive a realidade e a experiência da mudança, fui a campo para tecer uma pequena trama dessa história e realizei entrevistas temáticas com uma rede de colaboradores ligados aos CAPS da cidade, cujos discursos são capazes de confrontar documentos oficiais e práticas sociais. Além disso, possuem diversos traços de historicidade, apresentam certas regularidades e evocam a importância da arte em suas vidas. Ao mesmo tempo, trazem à tona muitos dos problemas enfrentados cotidianamente por esse grupo de pessoas que sofre duros processos de exclusão, o desemprego, o preconceito, a pobreza, a falta de oportunidades educacionais e de atenção especializada, o sucateamento do serviço público e as intervenções altamente medicamentosas.

Em uma história viva, vista de baixo e que se desenrola agora mesmo diante de nossos olhos, atravessada por uma memória individual e também coletiva, é que essa investigação dedicou-se a ouvir, registrar e a documentar as vozes dos silenciados pela própria história, almejando horizontes libertadores de futuro que reconheçam na prática os direitos garantidos em lei a todos os que necessitam desses cuidados.

Essas narrativas configuram-se como documentos que tem foco nas atividades voltadas à arte desenvolvidas por estes Centros, como estratégias importantes a favor da reabilitação psicossocial de seus usuários, conforme o que determina a legislação vigente. Essas narrativas objetivam também reafirmar sua potência e apresentar suas fortes críticas sobre o serviço, levantadas pelos entrevistados, tais como: a falta de investimentos na área, a superlotação, a má gestão, a rotatividade de profissionais e a precariedade das poucas oficinas terapêuticas realizadas por eles.

Cada entrevista teve duração de aproximadamente duas horas e, de acordo com os pressupostos da História Oral, passaram por um processo de transcrição e textualização, sendo conferidas e autorizadas pelos participantes e, por questões éticas, nelas foram utilizados pseudônimos para identificar os entrevistados, bem como, foram usadas apenas as iniciais de outras pessoas citadas, a fim de preservar suas identidades como no caso do jovem usuário do CAPS, cuja narrativa enviesada pelo intenso sofrimento psíquico e pela arte apresento agora.

Depois de alguns encontros, contatos telefônicos e troca de mensagens é que numa tarde ensolarada de domingo, às $16 \mathrm{~h}$, no dia 04 de junho, finalmente me deparei com Ronaldo, 25 anos, em uma praça da cidade, perto do Estádio Mineirão. Ele estava acompanhado da mãe, Sueli, e trazia nas mãos seu violão. Eu estava preparado com meu caderno de campo, um roteiro de questões e um gravador digital e começamos nossa conversa sobre a relação entre arte e saúde mental, perguntas que ele respondeu com a voz de quem contará uma história e assinará embaixo. Gravador ligado... 


\section{QUEM É VOCÊ E QUAL A IMPORTÂNCIA DA ARTE EM SUA VIDA?}

Eu sou Ronaldo. Para quem não me conhece eu passei por uma vida muito difícil, porque depois que eu descobri que eu tinha esquizofrenia, eu vi que minha vida ia acabar, que tudo ia parar, mas, eu vi que era realmente tudo ao contrário. Minha mãe me apoiou muito, me aceitou e viu o meu problema, porque no começo foi difícil para mim aceitar essa doença, esse problema. Foi aí que eu comecei a fazer tratamento, fazer terapia, conversar com os médicos. Eu comecei a entrar na música, na arte, eu comecei a tocar, cantar, a me desprender e aquela coisa depressiva que era ruim, que eu guardava dentro de mim, foi se libertando aos poucos, eu realmente deixei isso acontecer.

$\mathrm{Eu}$ vi aqueles pacientes, no mesmo estado que eu, e eu não queria que aquilo estivesse repercutindo só comigo, só com eles, eu queria transformar aquele ambiente, então eu levei a música, levei a arte, tudo o que eu sabia para eles e foi assim que aconteceu. A arte entrou na minha vida de forma muito relevante, porque quando eu comecei a entrar na música, nas artes plásticas, na pintura, no desenho, nas histórias em quadrinhos, eu comecei a desenvolver minha criatividade. Então, eu ganhei mais espaço e outros também ganharam espaço. Dentro de mim eu queria que no CAPS tivesse esse espaço para as pessoas exporem seu talento, exporem seu trabalho, porque a arte ela transforma, ela cura muitas vidas, isso é um fato importante.

\section{DE QUAIS ATIVIDADES TERAPÊUTICAS E EXPRESSIVAS VOCÊ JÁ PARTICIPOU NO CAPS?}

No CAPS já havia oficinas e eu participava de algumas, participei da oficina de dança que tinha lá e comecei a expressar mais a arte corporal, comecei a trabalhar com dança depois disso. Eu entrei na oficina de música onde havia um espaço aberto para todo mundo cantar o tipo de música que quisesse, aí comecei a cantar meus tipos de música e eu fui ganhando espaço e os pacientes também gostaram da minha música e eu fui participando e isso me confortou mais.

Porque o medo, angústia, aquela dor, todo medo que eu tinha, foi indo embora, porque foi através das oficinas, das terapias que tem lá que eu decidi mudar minha vida. Eu gosto muito de música, eu toco violão, canto, eu gosto de artes plásticas, sei pintar telas e também gosto de trabalhar com dança, trabalho muito com dança, é uma das modalidades que de fato eu gosto muito. Eu queria muito poder um dia trabalhar no teatro, já apresentei muitos espetáculos e tenho vontade de começar a trabalhar no teatro.

Também teve eventos que foram pelo CAPS como, por exemplo, o da UNIP que eu fui através da Cláudia, ela me indicou esse evento que era da saúde mental, a semana dos psicólogos que eu participei. A D. que falou para mim expor meus trabalhos, eu coloquei minhas histórias em quadrinhos que escrevi e coloquei minhas telas que é da minha história, é uma história em quadrinhos que eu escrevi.

Eu fiz uma música como trilha sonora da minha história em quadrinhos, aí apresentei tudo isso lá na semana dos psicólogos, na UNIP, eu apresentei para as pessoas, falei da minha vida e eu falei que a esquizofrenia não é um problema, mas, ela pode ser uma 
solução para a sociedade. Quem está doente pode se recuperar, é possível, eu creio que existe cura e a cura vem através da arte, que a arte ela cura, a arte é minha cura.

Durante essa semana foi o evento da prefeitura que eu participei, foi da luta antimanicomial que é a favor do fechamento dos hospitais psiquiátricos, participei da pintura solidária, fiz algumas telas, cantei. Teve outros eventos fora do CAPS que eu me apresentei, que foram eventos no SESC, também na luta antimanicomial do ano passado, na igreja, em aberto pela prefeitura, participei de muitos espetáculos dentro e fora do CAPS.

\section{COMO É O SEU TRABALHO ARTÍSTICO?}

Eu escrevo música desde novo e que são inspiradas na minha vida, na minha família, no meu cotidiano, baseadas em decepções amorosas, inspiradas em medos que eu já tive e que ainda tenho e também inspiradas por Deus, tanto nacional, quanto internacional eu escrevo músicas e também tem músicas que são inspiradas nas histórias que eu escrevo, no enredo, porque eu também sou roteirista das histórias, na verdade o protagonista da história sou eu.

$\mathrm{Na}$ verdade, todos são protagonistas de suas histórias e eu sou o protagonista da minha história. Desde novo sou muito criativo, faço pinturas em tela, desenhos, história em quadrinhos, isso tudo me transforma a cada dia mais, porque eu quero criar mais, porque a arte é algo infinito, nunca acaba, para mim a arte não tem fim. Eu aprendi uma coisa, que o segredo do sucesso é o silêncio. Não pode espalhar para todo mundo o que você vai fazer, tem que deixar tudo acontecer no momento, a arte de viver não consiste apenas só naquilo que você faz, no seu estilo de vida, no padrão certo, você pode criar esse estilo de vida, criar esse padrão. Arte é loucura para os olhos daquele que vê, mas, não para os olhos daqueles que sentem, porque a música me transforma, ela faz eu ir além do que eu sou e quando eu canto e toco, além de inspirar a mim, estou inspirando outras pessoas, realmente fazendo o bem para mim e para essas pessoas, levando uma mensagem positiva, é isso que eu quero para mim.

Essa música, Nuestro amor és um sueño, é tema da minha história em quadrinhos. Escrevo também em inglês, tem outra que vai sair, que é a segunda parte da minha história em quadrinhos, o volume dois, que é o "Give me power for to life", dar força para viver, que é uma história que vai comover. As personagens, vamos ter uma divergência, mas, elas vão voltar e se reunir novamente. As histórias em quadrinhos, eu tenho elas, eu publiquei, só que algumas eu acabei perdendo, conforme o tempo, mas, eu tenho algumas guardadas, se eu pudesse eu traria aqui.

Eu tenho um exemplar na minha casa da minha $\mathrm{HQ}$, então eu tive uma editora que me ajudou, uma gráfica, foi minha mãe que me indicou, que investiu e ela gostou muito do enredo da história e eu publiquei e o CAPS me ajudou muito e a Cláudia me indicou uma gráfica, uma editora, e fui lá e publiquei minhas histórias em quadrinhos.

Aqui fora, porque a prefeitura me ajudou muito, a cidade me ajudou, muitas pessoas daqui, da publicidade e do marketing, da televisão, me ajudaram bastante. Eu já dei entrevista para a TV TEM várias vezes falando sobre vergonha, falando sobre você não 
sentir vergonha de se apresentar em público, eu falei sobre esse tema e fui dando várias entrevistas, como no protesto da greve geral, mas, de fato todos os temas que eu abordava eram temas que eu estava vivendo ali no momento, no cotidiano.

O lançamento foi num estande na UNIP e foi muita gente de vários lugares, foi todos os alunos para ver esse estande, eu coloquei a tela das histórias em quadrinhos e o próprio gibi e vieram todos assinados com o meu nome e foi exposto e todo mundo teve acesso ao conteúdo, todo mundo leu a revistinha e gostaram muito do tema e agora estão pedindo para eu lançar o volume dois.

COMO É SUA RELAÇ̃̃O COM A FAMÍLIA?

Apesar de eu me sentir muitas vezes excluído da família, a relação que eu tenho com minha mãe, com minha família, eles foram muito presente s na minha vida, eu me excluia, não que eles me excluíram, porque eu sofria muito bullying na infância, eu tive uma infância muito conturbada, eu não era muito aceito pelo fato de eu ter um jeito de ser, uma expressão, uma opinião. Mas, a minha família veio, me agarrou e viu que alguma coisa estava errada e tinha que consertar, eu comecei a entrar em discussão por causa disso e conforme o tempo foi passando, eu fui entrando na igreja, comecei a aprender a tocar violão, comecei a cantar e minha família foi e me apoiou e me agarrou.

Depois que meu pai morreu, foi muito difícil lidar com isso, porque eu me traumatizei muito e essa perda me trazia muitos problemas, foi aí que meu psicológico acabou, foi ganhando cada vez mais força e foi aí que eu não tive mais controle e eu não pude mais continuar a fazer meus trabalhos, continuar estudando firme, eu acabei não indo mais na escola, daí depois voltei na escola. Depois de alguns dias, quando eu fui crescendo, acabei criando vários personagens. Um dia eu inventei que era indiano, no meio da escola e todo mundo achava que eu era indiano mesmo. E minha mãe na época, quando soube, ficou muito nervosa por isso, eu dei uma origem que eu não era, mas, foi assim que eu fui ganhando espaço, ganhando os meus amigos, sendo eu e criando essas personagens que hoje estão nas minhas histórias em quadrinhos.

Mas, a minha família sempre participou na minha vida, nas artes. Eu comecei a trabalhar com violão, logo depois dessa crise, tentei gravar um disco, mas, acabou não dando certo, mas, eu creio que vai dar certo, vou começar os trabalhos novos. A minha mãe quando vai trabalhar com terapias comigo ou com outros pacientes a gente já vê a diferença, já sai com outras expectativas, eu mesmo fico com autoestima até meio alta, pois, as coisas acontecem.

\section{COMO FOI A ESCOLA PARA VOCÊ?}

Terminei o ensino fundamental, o ensino médio, só que foi muito difícil porque quando eu estava chegando no final a diretora descobriu que eu tinha esse problema de esquizofrenia, porque eu brigava muito na escola, porque tinha uma diversidade de opiniões diferentes, inclusive religiosa. 
Eu cheguei a discutir com um professor ateu defendendo que a origem da vida foi criada por Deus, pelo sopro de Deus que o bebê irá nascer, só que o professor defendia o evolucionismo, mas, eu acredito no criacionismo. Levava meu violão na escola, cantava músicas de Deus e lutava contra isso e foi uma guerra até o final, até eu terminar a escola passei por uma guerra constante, minha mãe e minha família toda sabem disso, eles sabem tudo que eu passei.

Minha mãe é prova disso e agora eu ia fazer a faculdade de fisioterapia, mas, tive que trancar por causa do tratamento, porque eu tive alguns surtos e acabei com problemas, tive que parar com os estudos e tive que retomar as terapias. Eu pretendo voltar a estudar porque eu quero trabalhar, ter uma profissão, ter um lugar, ter um espaço para mim e ser a diferença para aqueles que também querem ser como eu. Eu queria ser pintor ou, senão, músico, terapeuta ocupacional e trabalhar na área da saúde ou trabalhar com a minha mãe, não sei, esses são meus projetos para o futuro.

\section{E COMO VOCÊ SOBREVIVE HOJE?}

Quem já não teve uma crise, quem já não teve medo, quem já não sofreu, quem já não se machucou, então o que eles passaram e o que eu estou passando não é uma complexidade, é um direito, estão revogando meus direitos como os deles também, nossos benefícios, ter nossos direitos, conquistar nosso espaço, não só na arte, mas, também na vida em si. Eu tenho consciência de que tenho meus direitos como cidadão, da parte social, as pessoas do CAPS têm o direito de ter uma vida digna, de ter boa alimentação, eles têm direito ao ônibus, direito ao acesso, têm direito ao trabalho, aos estudos e às oportunidades de emprego.

Acho que o CAPS deveria ter formas de ajudar no seu primeiro emprego, no primeiro trabalho, o CAPS deveria fornecer essas atividades para que eles se tornem pessoas melhores. Como eu estou precisando dos benefícios, o direito de receber a aposentadoria, o LOAS, o auxílio-doença, porque muitos perderam esse direito, eu perdi meu direito, porque o governo cortou tudo, mas, eu vou revogar, eu vou à justiça, eu vou lutar por isso e eles tem que fazer a parte deles, não é só eu, e se todos fizerem juntos a gente vai conseguir.

Eu recebia benefícios e deixei de receber e agora não consigo fazer um curso, não consigo estudar, não consigo fazer faculdade, não consigo comprar telas para pintar, não consigo comprar um violão novo, folha sulfite para fazer histórias em quadrinhos, lápis de cor, eu não tenho como fazer de outro jeito e eu tenho que ter um dinheiro para pôr em prática tudo isso que eu quero, tem que ter uma organização, dinheiro, tem que ter patrocínio, não é pelo fato de estar sem dinheiro, mas, faltar recursos e quando falta recursos aí complica um pouco a carreira, a parte artística.

Eu queria que toda Prefeitura, toda a organização do CAPS, que todo mundo fizesse um movimento para que houvesse geração de empregos assim como eles têm projetos de geração de renda, que são oficinas para poder gerar renda para o CAPS, eles deviam fazer um projeto de geração de renda para as pessoas do CAPS, não só para o CAPS, 
mas para as pessoas que estão lá, para aquelas pessoas que estão se tratando e precisam de dinheiro, de geração de renda, o trabalho seria muito importante.

De vez em quando eu vou ao cinema, eu sei que é livre, que eu posso, que eu sou especial e eu não pago, mas, não vou muito ao cinema, só quando tem lançamento, aí eu vou e esse é um direito que a gente já conseguiu conquistar, todo mundo. E isso de ir ao cinema só acontece aqui, em Sorocaba, em outras cidades eu não vi, eu queria que outras cidades pudessem também ter direito a ir ao teatro, em outros espetáculos, além do cinema, participar de shows, para ir em shows, por que é mais difícil excursão para esses lugares, você poderia pagar bem menos, acho que deveria montar um benefício para ajudar essas pessoas.

Eu enxergo a sociedade de uma forma, mas, eles me veem de outra, às vezes há divergências entre eu e a sociedade, porque eu penso de uma maneira e eles pensam de outra. Então, isso dificulta um pouco o meu contato com as pessoas, mas, eu fui conseguindo espaço, vendo eles, eu fui respeitando eles, a opinião deles e eles respeitando a minha, mas isso não vai divergir entre eu e a sociedade, meu contato social, isso não vai fazer que eu não tenha contato com a sociedade, que eu seja um monstro, que eu seja uma ameaça, na verdade eu não sou uma ameaça, eu não sou perigo algum para a sociedade.

$\mathrm{Eu}$ acho que a sociedade deveria ter um respeito ao meu problema e a todos os esquizofrênicos também, a gente também é humano e a gente tem nossos direitos, ter o nosso espaço, a gente tem livre arbítrio para trabalhar, para viver o seu estilo de vida, aí a sociedade não pode ver a gente como doente, como alguma coisa que nunca vai ter futuro, mas, ver que a gente tem futuro e que a gente tem lugar aqui no mundo. As pessoas têm muito preconceito, em certos lugares as pessoas se incomodam com a minha presença, às vezes acham que eu estou fazendo papel de louco, que tudo que eu faço parece que eu sou louco, que eu tô usando o vandalismo, que eu tô fazendo algo que é contra o que eles veem, para eles nós somos uma espécie de alienígena, não é bem assim, eles me enxergam de uma forma e eu os vejo de outra.

Mas, não é bem assim, sou ser humano, eles não têm que ter essa divergência comigo, mas, o preconceito ele tem muito, ele não vê a gente como se a gente fosse inferior a eles, a gente não é acima ou abaixo deles, eu não sou superior nem inferior a ninguém, estamos no mesmo patamar de todo mundo, é isso que a vida é.

\section{COMO OS CUIDADOS OFERECIDOS PELO CAPS SÃO IMPORTANTES EM SUA VIDA?}

Porque quando não tem terapia no CAPS, a gente reclama tanto que acaba desistindo de frequentar e eu queria poder continuar a lutar pela cura, pela compreensão. Porque às vezes você pode compreender a gente, mas, tem outras pessoas que não compreendem. Porque o esquizofrênico tem uma visão ampla das coisas, uma terceira visão. É uma coisa que nem todo mundo tem.

Eu queria que no CAPS tivesse oficina de teatro, de música, de violão, alguma coisa que nos acrescentasse mais, eu queria levar minha arte para eles, dar aula de violão para eles, pintura em tela. Agora a ideia do teatro surgiu porque eu já gostava de teatro, desde 
a escola, eu trabalhei na escola da família, nesse projeto eu ajudava muito as crianças e os adolescentes, eu trabalhei com todas as idades e continuo trabalhando.

Eu participo das oficinas não com muita frequência, vou duas ou três vezes por semana, na segunda-feira participo da oficina de psicoterapia, de quinta-feira, relaxamento, de quarta-feira, música. Tem outras atividades, tem futebol, só que eu vou todo dia no CAPS para tocar violão, porque eu gosto de levar música para os pacientes e eles cantarem comigo.

Então eu queria criar uma oficina para mim e para eles, para eles terem o espaço assim como eu também tive e eu estou lutando por isso. O doutor R. foi um grande médico, que me ajudou muito, ele tocava bateria, ele toca violão muito bem, ele ensinava violão para mim, ele me incentivou a trabalhar com música e isso era algo que ia me favorecer muito, ele me incentivou a criar um canal no YouTube, gravar meus vídeos, ele foi um pontapé para mim iniciar minha carreira artística.

Eu vou a um CAPS III, que fica na Vila Progresso e eu frequento lá já faz três anos, desde 2014, e eu tenho muitos amigos lá, além dos psiquiatras, médicos, terapeutas ocupacionais, e eu brinco com a G., que é responsável pela música e a T. e a M., todas essas pessoas me ajudaram muito, estão me ajudando até hoje, graças a Deus, porque se não fosse o CAPS eu não sei o que seria de mim. Para conseguir entrar nessas oficinas você tem que estar frequentando o CAPS, participando, conversando com os responsáveis pelas oficinas ou então entrar em contato direto com coordenador, vai passar no médico, ele vai dizer que oficina você deve participar, que vai fazer bem para a sua cabeça, será relaxante para sua cabeça, o médico vai indicar você para entrar em alguma oficina.

O CAPS é importante para mim, em minha trajetória, tanto dentro quanto fora, eu também trabalhei fora com a música, eu levei isso para fora, mas, eu não levei com a intenção de ter algo em troca, de algum valor, eu queria em troca os aplausos das pessoas e mostrar a importância da música na vida das pessoas, eu queria levar a música como uma cura para as pessoas, isso é um fator importante na minha carreira.

Todo mundo participa das oficinas, mas, tem as modalidades que a pessoa mais gosta, tem o pessoal do futebol, tem um pessoal da culinária, tem o pessoal da música, cada um tem uma oficina lá, vai do gosto, tem alguns que participam de uma oficina só e pode participar de todas. É uma questão daquilo que ele gosta, daquilo que ele quer também, porque se eles virem, eles participam, foi assim que eu também entrei, vi que a música podia entrar ali e eu comecei.

\section{COMO O SERVIÇO PRESTADO PELO CAPS PODE MELHORAR?}

Eu acho que poderia ser melhor, porque hoje em dia, vou falar a verdade, a prefeitura não está fornecendo alguns projetos, algumas oficinas, alguns trabalhos, a prefeitura diz que vai fazer uma coisa, mas, na verdade, fazem tudo pelo avesso, pela metade, os trabalhos, a voluntariedade, a solidariedade que eles têm que ter com as pessoas. O que eles estão fazendo é falta de ética e a burocracia que está dentro do CAPS não deixa as coisas acontecerem, as coisas não estão fluindo. 
Para que o CAPS aconteça é preciso mudar a parte da gestão, essa parte da questão pública, financeira, a prefeitura deveria aplicar mais recursos e ter mais organização, porque é muito desorganizado, então, para o CAPS ter futuro é preciso mudar a gestão, mudar a empresa, porque o que acontece?

Tinha uma empresa trabalhando lá e mudou para outra, então, o que aconteceu? Virou uma bagunça, as coisas não estão fluindo, o CAPS não é mais o mesmo que antes de dois anos atrás, as coisas continuam piorando, tem paciente reclamando, tem paciente surtando, médico que vai embora é muito, paciente que mata o enfermeiro, diversas coisas assim que são absurdas, é o cúmulo, chegou no extremo, no limite completamente, é porque falta profissionais mais competentes e falta organização, gestão das oficinas, porque quando o assunto é terapia, os pacientes vão e participam, os terapeutas vão lá para trabalhar e muitos deles vão e vão embora ou ficam no celular, na internet e esquecem que tem um compromisso conosco, com os pacientes, que nós necessitamos disso.

Então, isso acaba sendo um problema e muitas vezes a gente perde a visibilidade das terapeutas, dos psiquiatras, às vezes até do médico, porque o médico coloca um monte de coisas para você fazer, mas, você sabe que aquilo que você está fazendo vai interferir na sua vida, na sua vida pessoal, na sua vida familiar, então, tem coisas ali que o médico não está se organizando direito, que está dando muito problema, muita controvérsia, tem que mudar isso, tem que acabar isso e as coisas tem que mudar para melhor.

Terapia e medicamento, uma coisa, porque assim, os medicamentos não são especificamente distribuídos pela Policlínica, alguns medicamentos eu preciso comprar e são de alto custo. Alguns medicamentos têm, são pela Policlínica, mas, a questão da terapia e dos medicamentos é que o médico, às vezes, receita certas medicações que é fora do horário, fora do padrão, fora do tempo, que eu tenho que estar colocando no dia, no meu cotidiano, no meu dia a dia, na minha terapia. Então, isso está intervindo muito, está predominando demais, então, acho que eles deviam diminuir, eles têm que saber que o paciente tem que ter autocontrole, tem que ter coordenação motora para trabalhar certas coisas.

Eu acredito mais nos medicamentos porque as terapias alternativas não têm acontecido muito dentro do CAPS, não tem acontecido muito, se houvesse terapias alternativas ia melhorar, se tivesse menos medicamentos acredito que os pacientes não estariam na situação que estão hoje. Terapias alternativas como acupuntura, auriculoterapia, massoterapia, relaxamento, reflexologia, entre outras, a arte também, a musicoterapia, a pintura em tela, o teatro, a dançaterapia, mas, enfim, se tivesse mais terapias alternativas seria uma grande vantagem na vida dos pacientes, porque também tem essas outras alternativas, ele pode entrar no esporte, no futebol, basquete, entre outras modalidades, então, vai de acordo não só com o gosto do paciente, mas, para aquilo que ele quer tratar, ia realmente melhorar.

Para você ter uma ideia o CAPS não fornece tinta, tela, não tem violões para poder ajudar os pacientes a fazer musicoterapia, tá faltando recursos para o projeto de desenho, 
nem lápis de cor e caderno eles tem e o monte de coisas que estão faltando que não tem no CAPS. A minha mãe compra para mim fazer e os outros pacientes não fazem e reclamam: ai não tem nada aqui para mim fazer, não tem uma terapia para mim fazer. Reclamam que não tem terapia e para isso tem que ter uma organização, não tem dentista para cuidar da saúde, dessa parte da higiene do paciente, então, está uma situação, tem que melhorar, não pode continuar como está.

Antes tinha aquelas oficinas de pintura, cerâmica, guardanapo, biscuit e outras coisas que tinha. Vamos fazer máscaras? Tinha bastante oficina artística, mas, eles cortaram, porque entrou essa nova empresa e acabou interferindo em tudo. Quando a outra saiu tinha muitos terapeutas ocupacionais maravilhosos que caíram, todos os psiquiatras, médicos, até o médico que eu mais gostava, que eu tratei com ele, que me ajudaram, caiu. Teve um episódio de um incidente que foi muito triste, eu conheci ele pessoalmente, ele morreu no incidente, que o paciente matou ele a facadas, porque ele ia dar injeção nele, para ele ficar melhor e acho que não foi tanto culpa do paciente, porque ele estava em crise, em surto, tava fora de si, estava muito sem medicamento e foi um acidente que achei muito triste.

Fizemos uma homenagem para ele e até hoje isso me marca muito. Então, as coisas no CAPS precisam melhorar a segurança, precisa melhorar a saúde, então, envolve uma questão global. Ali, às vezes, o violão está sem corda e eu tenho que ficar comprando cordas para o violão, que nem é da minha responsabilidade, eles poderiam ir lá a coordenadoria do CAPS, o pessoal que trabalha na gestão, deveria ter as coisas, deviam ter mais responsabilidade nessa parte, deveria ter violões.

Eu já pedi, estou pedindo para que eles organizem, a prefeitura, e eles não entram em andamento, é muito demorado. Os pacientes levam o violão para o CAPS, quem tem. Esse violão é do CAPS, eu emprestei da T., eu tinha o meu violão só que ele quebrou em um acidente porque eu fiquei em surto e quebrei, mas, eu nunca fiz isso, eu só fiz isso porque eu estava sem remédio, eu tive acho que uns dez violões, acho que deviam fornecer violões para a gente ter oficina de violão no CAPS, ter música, eu queria ensinar eles a tocar violão, tem muitos que pedem, que querem aprender a tocar e não tem violão.

E eu fiz aula de canto e fiz aula de música por isso gostaria de multiplicar esse talento, tanto no violão, quanto na pintura em tela, nos desenhos, já tem alguns artistas lá, mas, é mais no violão mesmo que está precisando, os pacientes pedem para eu cantar, eu me sinto bem, quando eu vou lá eu me sinto bem, tem alguns dias que eu não estou bem, mas, quando pego o violão eu já melhoro, mas, aí eles pedem para eu tocar música, a gente faz uma roda e todo mundo canta, é maravilhoso, então, parece que eu estou transformando à mim e às outras pessoas, então, eu criei uma oficina ali no CAPS.

$\mathrm{Eu}$ acho que deveria acontecer mais projetos sociais para mobilizar, para que eles não tenham necessidade de tratamento com medicamentos, injeção, essas coisas que deixam eles mais perturbados e conturbados, então, se tivesse a arte presente lá dentro eles não precisariam sofrer tanto como agora, porque a arte vai mover a vida deles e vai trazer 
eles de volta para casa deles, a arte me trouxe para minha casa de volta, me fez voltar e reconhecer que realmente eu posso melhorar, eu posso mudar, eu posso ser uma pessoa melhor, com direitos assim como todo mundo tem, eu sou uma pessoa normal como todo mundo, mesmo tendo o meu problema, quem me vê não acha que tenho problema.

O CAPS que eu frequento é perto da minha casa, não é difícil de chegar porque eu pego o ônibus, eu pego o Vila Progresso, mas, se eu quiser ir a pé eu posso ir, porque fica dois ou três quarteirões da minha casa, mas, tem outras pessoas que frequentam lá e que moram muito longe, mas, para mim não é tanto, eu tenho acesso fácil ao CAPS.

O CAPS deveria fazer oficinas que são fora deles, não dentro deles, o CAPS deveria fazer atividades em outros lugares da cidade, em alguns parques temáticos, em outros lugares que houvesse encontros entre todos os CAPS que se reunissem para fazer algum projeto artístico, na parte de artes. Acho que devia ter, acho que os CAPS deveriam todos eles se conversarem, eu queria saber como é os outros CAPS, como é que eles são, que funções eles trabalham, que tipo de terapia eles trabalham, tudo eu queria saber e não tem essa junção, deveria ter essa junção, eu queria que houvesse, eu até hoje me pergunto: Quando será que os CAPS vão todos eles se juntar e fazer um projeto grande e todo mundo estar junto? As atividades poderiam acontecer fora, promover um evento fora do CAPS, porque assim, todo mundo se reunia, então todo mundo ia ganhar mais experiência, trocar mais novas experiências, ia ser algo maravilhoso o CAPS deveria ser um leque aberto, um livro aberto para tudo.

\section{O QUE VOCÊ PENSA PARA O FUTURO?}

Eu quero lançar logo a continuação de minha história, não vai ficar em "nosso amor é um sonho" tem que ter uma continuação, que já está sendo escrita, eu escrevo e desenho estilo mangá, um desenho japonês, tanto que eu já me apresentei em locais públicos para cantar, tocar música, violão, eu já apresentei dança, já apresentei na prefeitura, já me apresentei em festivais, já participei muito nessas áreas, mas, o que mais predominou mesmo, foi a música, mas, eu gosto das duas coisas, de várias coisas, de todas as modalidades, mas, acho que a música é o que mais me impacta.

Porque o Ronaldo personagem, ele quer ser um artista que anda pelo mundo e ele busca isso, ele quer que todo mundo o conheça, ele quer buscar a beleza, ele quer buscar uma grandeza interior, mas, aí a V. chega e transforma a vida dele e mostra para ele que não é bem daquele jeito que são as coisas, ele precisa primeiro encontrar o verdadeiro amor, porque ele tem o direito de fazer o que ele quer da vida dele, que é história que eu estou escrevendo agora que é a força para viver, ele precisa de força para viver, porque agora ele está vendo que ele está passando por uma má fama, está sendo muito criticado pelas pessoas e ele está tentando reconstruir isso, consertar os erros dele, e a V. está separada dele, mas, não sabemos se os dois vão voltar ainda, está nessa briga, Ronaldo seria eu no caso, já a V. seria uma pessoa que eu gostava há muito tempo atrás, uma pessoa que existiu, ela é uma personagem que existiu, só que foi um romance que não deu certo e eu queria que desce, mas, nunca deu, mas, nas minhas histórias ela está junto comigo. 
Agora vou publicar um trabalho novo, ir em busca de um novo começo, de um novo amor, ele está em busca. Eu estou com novos projetos, com novos trabalhos pela frente, quero começar a entrar no teatro, quero que minhas histórias virem peças de teatro, esse é meu maior sonho, eu tenho o maior sonho de me apresentar em outras faculdades também, levar isso para as pessoas, os meus trabalhos, ir para São Paulo, ir para alguns lugares do Brasil levar o meu trabalho, eu me sinto representando o CAPS, porque eu tenho que defender não só a mim, mas, a eles também, porque eu sinto a dor que eles sentem, eles sofrem como eu sinto, eles se emocionam quando eu me emociono, então o que eles passam, eu também passo.

Gravador desligado.

\section{REFERÊNCIAS BIBLIOGRÁFICAS}

BRASIL. Agência Nacional de Saúde Suplementar. Diretrizes Assistenciais para a Saúde Mental na Saúde Suplementar. Rio de Janeiro: ANS, 2008.

CAYRES, Aline Zoqui de Freitas. Et al. Caminhos para a desinstitucionalização no Estado de São Paulo: censo psicossocial 2014. São Paulo: FUNDAP: Secretaria da Saúde, 2015. 147p.

CONSELHO REGIONAL DE MEDICINA. Avaliação dos Centros de Atenção Psicossocial (CAPS) do Estado de São Paulo. Coordenação Institucional de Mauro Gomes Aranha de Lima. São Paulo: Conselho Regional de Medicina do Estado de São Paulo, 2010.

DELGADO, Pedro Gabriel Godinho. Saúde mental e direitos humanos: 10 anos da Lei n. 10.216/2001. Arquivos Brasileiros de Psicologia, Rio de Janeiro, v. 63, n. 2, p. 114-121, 2011. p. 114

SILVEIRA, Nise da. O mundo das Imagens. Rio de Janeiro, 1992. 165p. 